Volume 8, Nomor 1, 2020: 68-93

\title{
MANAJEMEN INTRAPERSONAL DAN INTERPERSONAL GURU RA BERPRESTASI DI YOGYAKARTA
}

\author{
Fu`ad Arif Noor \\ Sekolah Tinggi Pendidikan Islam (STPI) Bina Insan Mulia Yogyakarta \\ fuadarifn@stpi-bim.ac.id
}

\begin{abstract}
Abstrak
Kajian ini bertujuan untuk mengungkap manajemen kecakapan diri guru RA berprestasi yang berupa intra dan interpersonal di Yogyakarta, sehingga diperoleh guru RA yang berawal dari rasa tanggung jawab, berlanjut melaksanakan tugasnya dengan kecintaan yang dilandasi perasaan cinta, maka akan menumbuhkan sifat tidak mudah frustrasi bahkan putus asa, ikhlas, suka menolong, dan optimis. Rasa cinta kasih ini diwujudkan oleh peserta didik melalui rasa cintanya pada pekerjaan, cinta pada kebenaran, dan cinta kepada agama, negara serta bangsa. Guru yang mempunyai pandangan luas akan mampu memilih teknik yang tepat guna menghadapi keanekaragaman pada anak didiknya. Dengan adanya keanekaragaman tersebut, janganlah guru bersikap picik. Guru hendaknya menghargai beraneka ragam perbedaan yang ada disetiap individu peserta didiknya. Hal tersebut dilaksanakan agar proses pembelajaran bisa berhasil secara optimal. Seorang guru juga pandai bergaul dengan lingkungannya, terutama dengan anak didiknya. Guru yang pandai bergaul, akan dihormati dan akan dicintai oleh peserta didiknya. Pandai bergaul ini dapat dijalankan dengan pandai memposisikan dirinya, baik ketika bergaul dengan anak didik, wali atau orang tua anak didik, maupun masyarakat.
\end{abstract}

Keywords: Manajemen Intrapersonal, Interpersonal, Guru RA.

\begin{abstract}
This study aims to uncover the self-management skills of RA achievers in the form of intra and interpersonal in Yogyakarta, so that RA teachers who start from a sense of responsibility, continue to carry out their duties with love based on feelings of love, will foster the nature of not easily frustrated and even hopeless, sincere, like helping, and optimistic. This love is manifested by students through their love for work, love for truth, and love for religion, country and nation. Teachers who have broad views will be able to choose the right techniques to deal with diversity in their students. With this diversity, don't let the teacher be petty. Teachers should appreciate the diversity of differences that exist in each individual student. This is done so that the learning process can be optimally successful. A teacher is also good at getting along with his environment, especially with his students. Teachers who are good at getting along, will be respected and will be loved by their students. This sociable can be run by cleverly positioning himself, both when associating with students, guardians or parents of students, as well as the community.
\end{abstract}

Keywords: Intrapersonal Management, Interpersonal, RA Teacher. 


\section{A. Pendahuluan}

Pada diri guru berprestasi tertanam pada dirinya guru yang profesional. Istilah profesioanalisme terkait dengan: kualitas, mutu, dan perilaku yang menjadi karakter sebuah profesi serta orang yang profesional. Namun profesionalisme yang berasal dari kata profesi mengandung arti bidang pekerjaan yang berpedoman pada keahlian dan pendidikan (kejuruan, keterampilan, dan sebagainya) tersendiri yang dilakukan secara telaten oleh seseorang(W.J.S. Poerwadarminta, 1996:911).

Menurut Kunandar profesionalisme merupakan arah, kondisi, tujuan, nilai, dan kualitas suatu kewenangan dan keahlian yang bertalian dengan mata penghidupan seseorang. Profesi berarti pula sebagai suatu kedudukan atau pekerjaan khusus yang mensyaratkan keterampilan dan pengetahuan tersendiri yang dikuasai dengan melalui pendidikan akademis secara intensif(Kunandar, 2007:5). Selanjutnya mudjahit mengatakan bahwa profesi itu term yang menerangkan bahwa setiap pekerjaan sepatutnya dilakukan oleh individu yang memiliki keahlian dalam profesi atau bidangnya(Mudjahit, 2011:31).

Berdasar beberapa pengertian yang diuraikan dapat intisarikan bahwa profesionalisme menjadi sifat dari sebuah pekerjaan atau profesi. Sifat tersebut menunjuk pada pedoman melaksanakan tugas atau bertanggungjawab atas suatu pekerjaan atau profesi yang sesungguhnya. Profesi itu menjadi pekerjaan sekaligus jabatan yang menentukan kompetensi (pengetahuan, ketrampilan, dan sikap) diperoleh dari pelatihan dan pendidikan yang direncanakan secara khusus, artinya suatu kegiatan atau aktivitas yang dinamakan profesi tidak bisa dimiliki oleh sembarang orang. Dengan demikian profesionalisme berarti sebagai tanggung jawab bagi para personil suatu profesi guna mengembangkan kemampuan profesionalnya dan kontinu mengembangkan beberapa aturan yang dipakai dalam melaksanakan pekerjaan cocok dengan profesinya itu( Sudarwan Danim, 2016:23). Maka dalam melaksanakan tugas keprofesian perlu adanya profesionalisme yang menjadi bentuk kesungguhan serta tanggung jawab keprofesian.

Deskripsi perihal guru, yaitu orang yang profesinya, kegiatannya, mata pencahariannya adalah mengajar(Poerwwadarminta, 1996: 393). Diamanatkan dalam UU Tahun 2005 nomor 14 tentang Guru: bahwa guru ialah seorang pendidik profesional dengan mengajar, mendidik, membimbing, melatih, mengarahkan, mengevaluasi, dan menilai peserta didik sebagai tugas utamanya lewat jalur 
pendidikan dasar formal serta pendidikan menengah pada pendidikan anak (Mujtahid, 2011: 44). Penjelasan tersebut mengartikan bahwa guru menjadikan beberapa dari profesi atau kegiatan dengan ketrampilan tersendiri berkaitan terhadap proses pembelajaran dan pendidikan. Keahlian itu terdapat dalam penjelasan tugas guru, berawal dari mengajar, mendidik, hingga mengevaluasi atau assessment dalam ruang lingkup pendidikan formal. Namun, pendapat lain menjelaskan bahwa pengertian guru lebih leluasa dari itu. Moh. Uzer Usman menyinggung bahwa guru itu jabatan profesi yang membutuhkan skill khusus sebagai pendidik (Mutjahid, 2011:33).

Oleh karenanya guru menjadi salah satu komponen mendasar dalam dunia pendidikan. Ruh pendidikan sesungguhnya berada di pundak guru, baik buruknya atau sukses tidaknya pendidikan hakikinya ada di tangan guru. Figur guru memiliki andil yang strategis dalam membentuk peserta didik supaya menjadi cerdas, pandai, terampil, berpengetahuan luas, serta bermoral. Penjelasan perihal pengertian guru menunjukkan alasan seorang guru itu mutlak memiliki jiwa profesionalisme. Posisi guru sangat strategis dikehendaki melalui jiwa profesionalisme mampu mengembangkan aktivitas pendidikan berkualitas yang sekaligus menjadi pilar kokoh teruntuk lembaga satuan pendidikan(Mutjahid, 2011:6).

Pengalaman mengajar sebagai guru kelas bagi Guru RA berprestasi menjadikan aktif dalam mengikuti kegiatan forum ilmiah tingkat lokal berupa: pelatihan program pendidikan serta kecakapan hidup pada daerah khusus (kewirausahaan), demikian pula melakukan pembimbingan terhadap teman sejawat meliputi: program pelatihan pendidikan kecakapan hidup dalam meraih keinginanan maupun cita-cita pribadi (Wawancara Ibu Estri Ritah Indriwati, 2019).

Metodologi yang digunakan alam kajian ini adalah kualitatif dengan menggunakan pendekatan psikologis. Taylor dan Bogdan mengartikan metodologi kualitatif menjadi prosedur penelitian yang melibatkan data deskriptif tertulis maupun kata-kata lisan terhadap orang-orang ataupun informan yang dapat diamati (Lexy $\mathbf{J}$ Moleong, 2005: 3). Penulis berusaha mengetahui arti peristiwa dalam kaitannya dengan objek penelitian dan situasi penelitian. Pendekatan ini memberi arahan pada makna interpretatif terhadap peristiwa-peristiwa kehidupan guru di sekitar RA. Lexy J. Moleong menyebutkan dengan istilah "verstehen"( Lexy J Moleong, 2005: 9). Penulis berusaha mendekatkan diri ke dalam ranah konseptual obyek penelitian, sehingga pengertian substansial dapat dikembangkan di sekitar wilayah kehidupan 
sehari-hari di sekitar RA.Penelitian ini bersifat deskriptif analitik, karena penelitian ini berupaya menguraikan situasi yang diteliti dalam wujud uraian naratif, di mana masalah pokok penelitian menjadi fokus penelitian(S. Nasution, 2003: 31) sementara diuraikan dalam wujud naratif dengan memaparkan uraian-uraiannya bersifat analisis.

Terdapat 3 (tiga) tahapan yang sedang peneliti lakukan dalam mencermati hal tersebut. Pertama, Peneliti berusaha masuk dalam tahap reduksi data, ialah tahap mencermati peristiwa-peristiwa yang sedang dikaji; kedua, Peneliti berusaha menyusun bagian-bagian peristiwa-peristiwa yang akan dideskripsikan, dengan maksud untuk mendapatkan makna-makna dari peristiwa pada diri o byek penelitian, lalu tahap; ketiga, Peneliti masuk dalam transformasi makna, di sini mulai menyusun analisis dan dan uraian deskriptif(Jhonathan A. Smith, 2013: 445-46).

\section{B. Pembahasan}

\section{Profesionalisme Guru}

Di Indonesia guru profesional dipersyaratkan memenuhi: (1) Landasan ilmu yang kokoh sebagai manifestasi terhadap masyarakat berilmu pengetahuan, serta masyarakat berteknologi, (2) Pemahaman berbagai kiat profesi berlandaskan penelitian dan praktik pendidikan adalah ilmu pendidikan menjadi ilmu praksis bukan sekedar sebagai konsep-konsep belaka. Pendidikan menjadi sistem yang terjadi bersifat ilmiah, di lapangan serta penelitian pendidikan hendaknya difokuskan pada praksis atau praktik pendidikan masyarakat Indonesia, (3) Peningkatan kompetensi profesional berkelanjutan, profesi guru menjadi profesi yang tumbuh terus menerus serta berkelanjutan antara praktek pendidikan dengan LPTK. Kekerdilan ilmu pendidikan dan profesi guru dikarenakan terputusnya program in-service dan preservice sebab pertimbangan birokratis yang ketat atau kaku, atau manajemen pendidikan yang lemah (Imron Arifin, 2001:6).

Syarat-syarat profesionalisme bagi guru di atas apabila terpenuhi, maka mengganti peran guru yang awalnya pasif berubah menjadi guru yang dinamis serta kreatif, sehingga penentuan persyaratan profesionalisme bagi guru akan merubah peran guru yang awalnya sebagai orator (pandai berpidato) yang verbalistis (bersifat penyidikan) menjadi kecakapan yang dinamis dalam mewujudkan suatu suasana lingkungan pembelajaran yang learning environment (Conny R Semiawan, 1991:63).

Profesionalisme guru menjadi rendah, ada 5 (lima) penyebab utama ialah: (1) Banyak guru belum memenuhi profesinya secara menyeluruh berkelanjutan, (2) 
Rendah dan rentannya kepatuhan guru terhadap nilai atau norma serta etika profesi atau akhlak keguruan, (3) Pengesahan terhadap ilmu keguruan dan pendidikan masih belum utuh dan bulat dari beberapa pihak terlibat dalam pengambilan kebijakan. Terbukti masih kurang mapannya kelembagaan yang melahirkan tenaga kependidikan dan keguruan, (4) Masih kurang smoothnya perbedaan paradigma tentang proporsi atau keseimbangan bahan ajar yang dimodalkan kepada calon guru yang profesional, (5) Masih kurang berfungsi PGRI secara optimal sebagai lembaga atau organisasi profesi yang berusaha semaksimal untuk meningkatkan profesionalisme para anggotanya.

Upaya untuk mengembangkan profesionalisme bagi guru di antaranya dengan cara: (1) Peningkatan kualifikasi yang mensyaratkan mengikuti pendidikan jenjang lebih tinggi untuk tenaga pengajar atau pendidik. (2) Program memperoleh sertifikasi(Pantiwati, 201:1-11). Selain sertifikasi, untuk memaksimalkan peran dan fungsi aktivitas dalam wujud berupa Pusat Kegiatan Guru, Kelompok Kerja Guru, serta bentuk Musyawarah Guru Mata Pelajaran yang menjadi lahan bagi guru untuk curhat berbagi pengalaman dalam hal memecahkan berbagai masalah yang mereka lalui dalam kegiatan mengajarnya(Dedi Supriadi, 2005:66)

Pengembangan atau pembinaan profesi para guru meliputi: (1) bekal diri belajar lebih lanjut. (2) ikut mengusahakan dan menghimbau sarana serta fasilitas beberapa sanggar misalnya sanggar penguatan kerja guru. (3) ikut mengusahakan jalan keluar agar guru-guru memperoleh peluang lebih besar untuk melaksanakan pelatihan, workshop dan penataran-penataran pendidikan. (4) ikut memperluas peluang agar guru-guru mampu nelaksanakan berbagai seminar pendidikan yang cocok dengan bakat, minat serta bidang studi yang diampunya dalam usaha meningkatkan profesinya. (5) menyelenggarakan berbagai diskusi ilmiah secara periodik berkala disekolah. (6) menumbuhkan teknik belajar berkelompok bagi guru-guru serumpun studinya(Pidarta, 1999:31).

Pola pembinaan atau pengembangan terhadap profesi bagi guru yang dijelaskan di atas sangat menguatkan terjadinya transformasi atau perubahan paradigma dalam peningkatan profesi guru merupakan langkah antisipatif terhadap peralihan fungsi dan peran guru yang saat ini diterima sebagai sumber utama informasi maupun pengetahuan bagi peserta didik. Padahal perkembangan teknologi dan informasi sekarang ini sesuai apa yang diungkapkan oleh ibu Sri Ngadiyati sebagai guru RA 
berprestasi, bahwa: perkembangan fungsi gadget atau hp android itu tmampu membuka peluang kesempatan bagi setiap individu untuk bisa belajar dengan mudah secara mandiri serta cepat, ini berarti siapapun dapat lebih dahulu mengetahui kejadian sebelum orang lain mengetahuinya, kondisi ini menandakan adanya pergeseran pola pembelajaran atau perubahan peran serta fungsi guru yang lebih besar, bukan lagi menjadi sumber utama pengetahuan dan informasi bagi anak didik, melainkan mampu menjadi fasilitator yang mengarahkan anak didik dalam pembelajarannya(wawancara Ibu Sri Ngadiati, 2019).

Rina Wahyuni sebagai guru RA berprestasi menyatakan bahwa: 'Pengembangan profesi guru hendaknya diikuti dengan usaha lain seperti mengusahakan perpustakaan khusus untuk guru-guru yang mencakup kompetensi perkembangan peserta didik melalui pendekatan tema-tema diajarkan di RA, sehingga seorang guru itu tidak terlalu sulit untuk mencari bahan materi dan referensi untuk mengajar di kelas. Pengembangan lain bisa dilakukan melalui pemberian peluang dan kesempatan bagi guru-guru untuk menyusun materi kegiatan anak yang menjadi buku tambahan bagi anak didik atau murid, baik yang bersifat perorangan atau berkelompok yang berupa lembar kerja anak atau buku pegangan untuk anak didik maupun buku pegangan untuk gurunya. Usaha ini bisa memotivasi guru untuk melakukan inovasi dan meningkatkan kreativitasnya, berarti juga memberikan kesempatan guru untuk meningkatkan kinerjannya"(Wawancara Rina Wahyuni, 2019).

W.F. Connell menyatakan perihal guru profesional yaitu guru yang mempunyai kemampuan tertentu cocok dengan ketentuan yang ditetapkan oleh profesi keguruan. Peranan profesi ialah sebagai supervisor, motivator, penanggung jawab membina kedisiplinan, pengelola administrasi kelas, model teladan perilaku, pengajar yang senantiasa mencari ide dan pengetahuan baru untuk meningkatkan dan melengkapi pengetahuannya, pembimbing dan pengajar dalam proses belajar, komunikator orang tua wali murid dengan masyarakat, serta sebagai anggota organisasi profesi pendidikan(W.F.Connel, 1974:77).

Menyadari akan profesi tersebut menjadikan wujud real eksistensi guru menjadi komponen yang berkewajiban dalam keberhasilan pendidikan, sehngga menjadi satu keharusan bahwa guru mempunyai kesadaran akan fungsi dan perannya sebagai pendidik. Kesadaran diri menjadikan inti dari dinamika gerak laju pertumbuhan profesi seseorang yang merupakan sumber dari kebutuhan mengaktualisasikan diri. 
Semakin tinggi akan kesadaran seseorang maka semakin kuat keinginan meningkatkan profesinya(Pidarta, 1999:33).

Dalam rangka menjalankan semua tugas dengan terpuji, guru RA berprestasi memerlukan kemampuan merencanakan pengajaran, menyusun tujuan pengajaran, menyajikan materi atau bahan pelajaran, mengajukan pertanyaan kepada peserta didik, mengenalkan konsep, berkomunikasi dengan peserta didik, mencermati kelas, dan menilai hasil pembelajaran. Mengajar itu kompetensi guru yaitu kesanggupan atau kemampuan guru dalam memanaj pembelajaran. Titik tekannya yaitu kepiawaian mengajar guru dalam pembelajaran bukan hanya apa yang dimengerti (studying what to be learn), melainkan guru dituntut mampu mewujudkan dan menggunakan keadaan kondusif atau positif untuk membawa dirinya ke dalam proses pembelajarn agar anak dapat mengembangkan potensinya. Guru dapat mengembangkan dan menafsirkan isi kurikulum yang dipakai selama ini pada jenjang pendidikan yang diterapkan sesuai walaupun latar belakang ekonomi, sosial, budaya yang pelbagai ragam.

Beberapa aspek keteladanan mental guru RA berprestasi pada khususnya akan berpengaruh kuat terhadap pemikiran pelajar dan iklim belajar yang dimunculkan guru. Guru mengerti bahwa sikap dan perasaan peserta didik akan ikut andil serta berpengaruh positif pada proses pembelajarannya. Guru yang berkompetensi agar mampu memiliki jiwa inovatif, meninggalkan sikap konservatif, kapabel (mampu, cakap, pandai, sanggup) dan kreatif, tidak bersifat defensive atau bersikap bertahan, melainkan mampu membuat peserta didik lebih bersifat ofensif atau tanggap(Balnadi Sutadipura, 1994: 21).

Penguasaan seperangkat kompetensi yang berupa kompetensi baik keterampilan proses maupun kompetensi penguasaan pengetahuan merupakan unsur yang dikolaborasikan dalam bentuk satu ketunggalan yang utuh menyatu dan membentuk struktur kompetensi yang dikuasai oleh seorang guru. karena kompetensi menjadikan seperangkat kemampuan guru sejajar dengan kebutuhan pendidikan di sekolah, tuntutan masyarakat, dan pertumbuhan ilmu pengetahuan serta teknologi (wawancara Subyekk Gupres 5, 2019).

Kompetensi keterampilan proses pembelajaran yaitu kemahiran terhadap kemampuan yang bertalian dengan proses pembelajaran. Sedangkan kemampuan mengajar guru sebetulnya merupakan pencerminan keterampilan guru terhadap kompetensi dasar yang dikuasai, diantaranya memahami bahan, menguasai landasan 
kependidikan,menetapkan program pengajaran, menjalankan program pengajaran, mengevaluasi, melakukan proses bimbingan serta penyuluhan, keadministrasian sekolah, meningkatkan kepribadian dan hubungan sosial serta mengadakan penelitian untuk kepentingan pembelajaran(Ali Imron, 1995:44).

Selama itu kompetensi atau kemampuan mengajar bagi guru menjadi sangat urgen dalam melaksanakan fungsi dan tugasnya, tanpa adanya kecakapan mengajar yang terpuji, sangat tidak mungkin atau mustahil guru dapat melaksanaan kreasi atau inovasi dari bahan materi yang ditetapkan dalam kurikulum, nanti pada gilirannya akan memberikan rasa bosan sekaligus jenuh bagi guru atau peserta didik untuk menjalankan fungsi dan tugas masing-masing(Ali Imron, 1995:44).

Pada lingkungan kerja hubungan sosial manusia selalu terjadi antar manusia, sebagaimana penelitian yang dilakukan Terence R. Mitchell menyimpulkan perihal tidak sedikit orang berada dalam organisasi itu menghabiskan semua waktunya guna interaksi interpersonal(Sodiah dan Euis Nurhikmah, 2017:185). Hubungan yang ada antara pimpinan atau atasan dan bawahan, antara sesama bawahan, di sekolahpun atau RA hubungan dapat terjadi antara guru dan kepala sekolah, antara peserta didik beserta guru, atau antara guru dengan sesama guru. Hubungan guru beserta anak didik lebih sering berhubungan ketimbang dengan hubungannya dengan sesama guru atau bahkan hubungannya dengan kepala atau pimpinan sekolah. Setiap hari guru bertatapan dengan anak didik yang jumlahnya banyak terkadang sangat merepotkan, namun secara khusus bagi guru interaksi jalinan komunikatif dengan siswa menjadi hal yang menarik serta mengasyikkan apalagi dapat menolong peserta didik dalam menyelesaikan cara mengatasi kesulitan belajarnya(wawancara Ibu Esti Ritah Indriwati, 2019).

\section{Manajemen Intrapersonal dan Interpersonal Guru RA Berprestasi}

Intrapersonal adalah kecakapan seorang guru ditinjau dari dirinya sebagai makhluk individu, di mana setiap individu memiliki softskill yang bisa dikembangkan. Misalnya tekun, rajin, ramah, dan lain-lain. Sedangkan interpersonal adalah kecakapan seorang guru ditinjau dari dirinya sebagai makhluk sosial, di mana keberadaannya selalu membutuhkan bantuan orang lain, butuh keterhubungan dan saling bekerjasama dengan manusia lainnya. Misalnya berbagi tugas dalam suatu kepanitiaan, dan lainlain(Wawancara Rina Wahyuni, 2019). 
Seorang guru RA berprestasi itu memiliki peran terhadap dunia pendidikan yang dapat dirasakan adalah perubahan karakter peserta didik. Setiap pembelajaran yang disampaikannya, selain mencapai nilai akademik, guru RA berprestasi juga menekankan pada pengembangan karakter peserta didiknya. Hal itu tampak terlihat dari perubahan sikap yang dialami peserta didik pembelajaran yang diampu olehnya, lebih konkrit lagi adalah kelas yang dipegang olehnya karena dia juga sebagai pendamping dari wali kelas RA B2. Contoh perubahan sikap yang dialami anak adalah ketika sholat gerakan dan bacaannya lebih baik, sikap dalam berteman lebih sopan dan santun, adab ketika makan dan minum lebih diperhatikan, ketika pembelajaran berlangsung lebih memperhatikan guru kelas tersebut daripada yang lainnya(Observasi , 2019).

Kepribadian secara harfiyah berasal dari kata yang berbahasa Inggris personality. Dalam bahasa Yunani kata personality berawal dari kata per kemudian sonare berarti topeng, juga berasal dari personae berarti pemain sandiwara, ialah pemain yang memakai topeng tersebut(Nana Saodih Sukmadinata, 2007:136). Kepribadian ini juga bisa dipahami sebagai sifat nyata yang berada di belakang atau di balik sikap yang ditampilkan oleh individu atau seseorang. Sifat ini merupakan sifat yang khas yang telah menyatu pada diri seseorang sehingga seseorang dapat dinilai apakah dia berkepribadian yang baik atau tidak.

Manusia menjadi mahluk sosial memiliki nilai-nilai kesempurnaan secara fisik, mental spiritual dan intelektual, menyatu dalam jasad yang menggambarkan sosok kepribadian manusia yang unik. Kepribadian yaitu sesuatu yang kompleks terhadap konsep individu, yang didalamnya ada karakter, tabiat dan watak, meskipun dalam realitanya karakter dalam kehidupan yaitu implementasi tabi`at (Khoiri Fatimah, 1998 : 11). Watak bisa digolongkan ke dalam tiga unsur yang menyatu, yaitu: keaktifan, berupa semangat dalam bentuk kemauan, pendapat yang terang diaktualkan dalam bentuk fikiran, dan perasaan harus selalu muncul dalam wujud rasa (Ag. Soejono, 1978 : 131). Perpaduan tabìat, watak, karakter dan temperamen menggambarkan kualitas kepribadian untuk berbuat, berfikir, berpendapat, bersikap, minat dan filsafat hidup serta kepercayaan keagamaan(Muhammad bin Abdurrahman, 1991 : 152).

Motivasi dirinya untuk berkontribusi dalam dunia pendidikan, terutama menyusun buku/modul bahasa Inggris berawal dari fenomena problematika pengajaran bahasa Inggris yang mengganggu fikirannya. Selama ini anak belajar memakai buku paket 
ukuran besar dan tebal, selain itu harganya juga cenderung mahal. Di sisi lain juga disediakan buku LKA atau dikenal dengan lembar kerja anak oleh sekolah, di mana kemasannya kurang menarik, padat materi dan soal dengan font yang cenderung kecil. Maka untuk menjembatani itu, disusun buku/modul bahasa Inggris dengan mengakomodir unsur-unsur yang termuat di buku paket dan LKA. Buku paket umumnya banyak gambar warna dengan font yang nyaman, di mana unsur tersebut sangat digemari anak, sedangkan LKA ciri utamanya adalah memuat soal-soal dengan jumlah yang banyak. Perpaduan dari hal-hal tersebut maka dibuat modul bahasa Inggris dengan ukuran mungil seperti buku tulis pada umumnya, dengan muatan yang dikondisikan sesuai perkembangan atau kebutuhan anak yang dipadukan dari materi beberapa buku paket, juga memuat banyak gambar dan soal-soal yang jumlahnya cukup mewakili isi materi dalam setiap bab (Wawancara dengan Rufiyati Ambar Ningrum, pada 25 September 2019).

Pada prinsipnya jiwa seseorang dapat dikategorikan menjadi 2 aspek, yaitu aspek ability atau kemampuan dan juga aspek kepribadian atau personality. Aspek kemampuan mencakup: prestasi belajar, intelegensi, serta bakat; sedangkan aspek kepribadian terdiri dari: sifat, watak, penyesuaian diri, minat, dan sikap, serta motivasi (Samsi Haryanto, 1994: 1). Kedua aspek tersebut akan selalu menyertai seseorang, termasuk guru dalam kehidupannya. Penyertaan itu dapat berbentuk dorongan maupun larangan. Mengenai kepribadian, para pakar kejiwaan secara umum menjelaskan bahwasannya kepribadian itu menjadi suatu mekanisme yang mengarahkan dan mengendalikan perilaku dan sikap seseorang (Zakiah Daradjat, $1995: 62)$

Seseorang yang dengan spontan dan selalu menampilkan suatu sifat tertentu tanpa ada pengaruh dari luar dirinya ataupun motivasi tertentu, maka dapat dinyatakan bahwa sifat yang ditampilkan tersebut merupakan kepribadiannya. Apabila personality atau kepribadian seseorang kokoh, maka sikapnya akan menjadi tegas dan jujur, tidak mudah dipengaruhi oleh rayuan dan berbagai faktor yang datangnya dari luar, serta ia mau dan mampu bertanggungjawab atas perbuatan dan ucapannya. Namun, apabila kepribadiannya kendor, maka ia akan mudah tergoyang oleh berbagai pengaruh yang datangnya dari luar. Secara umum, kepribadian menjadikan suatu organisasi yang cukup dipunyai oleh manusia, yang menjadi pengendali atau penentu perilaku maupun pemikirannya. 
Kepribadian juga disamaartikan dengan istilah karakter ataupun temperament. Ketiga istilah tersebut mempunyai arti yang berkaitan. Namun, masing-masing istilah kata tersebut memiliki kekhususan tersendiri. Istilah karakter lebih menuju kepada tabiat yang bisa disebut salah atau benar, tidak sesuai atau cocok dengan beragam nilai sosial yang ditetapkan (Ahmad D. Marimba, 1980: 66). Seseorang yang mempunyai tabiat baik atau cocok dengan nilai-nilai sosial, akan disebut sebagai orang pribadi yang berkarakter terpuji. Dan kebalikannya, orang yang mempunyai tabiat buruk atau tidak sesuai dengan nilai-nilai sosial, ia akan disebut sebagai pribadi berkarakter buruk. Penjelasan tersebut terlihat bahwa ukuran yang dipakai sebagai acuan penilaian yaitu peraturan yang ditetapkan di masyarakat (Wawancara dengan Rina Wahyuni, pada 28 September 2019).

Secara garis besar poin terpentingnya aspek kepribadian bisa digolongkan menjadi 3 (tiga) aspek, yaitu aspek kejasmanian, aspek kejiwaan, dan aspek kerohanian (Aspek kejasmanian meliputi tingkah laku luar, misalnya cara berbuat, cara berbicara, dan sebagainya. Aspek kejiwaan meliputi aspek-aspek yang tidak dapat dilihat dari luar, misalnya cara berpikir, sikap (pandangan seseorang dalam menghadapi sesuatu), dan minat. Aspek kerohanian meliputi aspek kejiwaan yang lebih abstrak yaitu filsafat hidup dan kepercayan. Ahmad D. Marimba, Pengantar Filsafat Pendidikan Islam, 67).

Aspek kejasmanian merupakan aspek yang langsung bisa terlihat. Karena dapat dilihat secara langsung, maka orang lain dapat segera menilainya. Sedangkan aspek kejiwaan merupakan aspek yang sulit untuk dapat segera dinilai. Untuk dapat mengambil kesimpulan aspek kejiwaan orang lain, seseorang memerlukan tenggang waktu. Hal ini dapat dilaksanakan dengan banyak bergaul dengan seseorang tersebut. Dari pergaulan tersebut, maka pribadi kejiwaan orang lain dapat mulai dipahami. Aspek kerohanian menyangkut keyakinan seseorang. Aspek ini dapat menjadi aspek yang sangat mendasari dan juga merupakan penentu dalam kehidupan sosial seseorang. Aspek kerohanian dapat mendorong seseorang menghindari sifat iri, dengki, dan penyakit hati lainnya(Wawancara dengan subyek keempat sebagai gupres harapan I Saudara Anton Ariyadi, pada tanggal 16 September 2019).

Kepribadian saya mulai dari aktivitas penyambutan, "Saya menyambut anak beserta orang tua dengan $5 \mathrm{~S}$ (senyum, salaman/salam, sapa/memanggil namanya, sopan, dan santun) penuh dengan kehangatan dan keramahan". Perihal kedisiplinan 
saya: "Setiap kali jam datang atau pulang harus disiplin tepat waktu, bahkan sebelum jam masuk sudah berada di sekolah, mematuhi tata tertib, tidak suka bolos, mengerjakan tugas sesuai tanggal yang ditentukan". "Begitu juga kesabaran sebagai guru berprestasi tidak mudah untuk menjadi teladan apalagi disekitar banyak guruguru RA yang lebih senior. Saya harus menguasai kemampuan pedagogik, kemudian kepribadian, lalu sosial, berikutnya manajerial, dan supervisi, serta kewirausahaan. Sabar dalam membimbing guru yang mempunyai sedikit banyak kekurangan maupun kelebihannya dari masing-masing. Dalam keuletan atau ketelatenan: "Seorang guru berprestasi harus telaten karena kalau mutungan bisa semua program tidak jalan dan harus lapang dada, ati segoro". Keuletan atau tekun dalam melaksnakan tugas harus menjalin kerjasama dengan pihak terkait, koordinasi dengan guru, orang tua wali murid, komite, yayasan, serta tokoh masyarakat. Bila ada masalah kita selesaikan secara kekeluargaan internal terlebih dahulu dengan yayasan serta berkonsultasi dengan dinas terkait" (Observasi dan wawancara dengan ibu Rufiyati Ambarningrum pada 16 September 2019).

Kompetensi kepribadian adalah kecakapan kepribadian yang berakhlak mulia, mantap, berwibawa, dan arif, serta menjadi teladan bagi peserta didik (Undangundang RI No. 14 Tahun 2005 Tentang Guru dan Dosen). Perihal ini merupakan sesuatu yang penting dalam diri seorang guru. Faktor terpenting yang menyatu dalam diri seorang guru yaitu kepribadiannya. Kepribadian menjadi suatu organisasi yang hanya dipunyai oleh manusia, yang menjadi penetap perilaku dan pemikirannya (Haryanto, 2). Keadaan ini sesuai dengan salah satu keinginan yang hendak diperoleh dalam sistem pendidikan, yakni mewujudkan kepribadian anak didik. Kepribadian itulah yang nantinya akan menetapkan apakah guru akan menjadi pembimbing yang mulia bagi muridnya, atau justru menjadi penghancur masa depan muridnya.

Dalam proses perwujudannya, kepribadian seorang individu dipengaruhi oleh faktor biologis atau genetik, perubahan lingkungan, dan pengalaman sosial. Untuk lebih ringkasnya, faktor situasi dan kondisi lingkungan serta faktor pembawaan berpengaruh terhadap kepribadian individu seseorang. Pembawaan menjadi faktor penting dalam membangun kepribadian seseorang. Seorang anak sejak dini sudah dibekali dengan potensi dalam dirinya, yang merupakan pembawaan sebagai anugerah dari Tuhan semesta alam Yang Maha Esa. Disamping potensi dari Tuhan, lingkungan 
memiliki peran yang lebih penting dalam membangun kepribadian anak. Lingkungan tersebut mencakup lingkungan sekolah, keluarga, dan juga masyarakat.

Agar dapat membentuk kepribadian muridnya dengan baik, maka guru wajib mempunyai kepribadian terlebih dahulu. Namun, kepribadian yang sesungguhnya yaitu abstrak sehingga sulit dilihat secara nyata. Meskipun demikian, kepribadian dapat diketahui dari penampilannya secara lahir (Zakiah Daradjat, 2005 : 13). Seperti dalam ucapan, tingkah laku, cara bergaul, cara berpakaian, serta dalam menghadapi semua persoalannya. Dari penampilan tersebut, murid atau anak didik bisa menilai kepribadian gurunya. Dan hal yang perlu dïngat bagi guru yaitu bahwa peserta didik bukan sekedar menilai gurunya ketika ia berada di lingkungan sekolah. Di lingkungan luar sekolah pun, ia harus tetap menampilkan nila-nilai keutamaan agar anak didik menjadi semakin mantap dalam menjadikannya sebagai model bagi mereka.

Seorang guru bisa dikatakan berkepribadian apabila ia telah memiliki normanorma tertentu, dengan istilah lain guru perlu mempersatukan dirinya dengan normanorma termaktub (Zakiah Daradjat, 2005 : 19). Dengan menyatunya norma-norma dalam dirinya, maka guru akan menjadikan pribadinya yang utuh sehingga guru pantas menjadi sosok teladan. Dengan adanya penampilan-penampilan yang berada dalam diri pribadi seorang guru, maka kategori kepribadian tidak menjadi kabur.

\section{b. Guru sebagai Teladan}

Kecondongan manusia untuk meniru atau belajar lewat peniruan membuahkan keteladanan menjadi sangat berarti dalam proses pembelajaran(Ramayulis, 2004 : 181). Keteladanan merupakan sesuatu atau hal yang bisa dicontoh atau ditiru. Keteladanan terungkap dalam bahasa Arab, dengan istilah kata uswah ataupun qudwah yang berarti perilaku yang dapat dicontoh oleh orang lain terutama peserta didik. Keteladanan menjadikan salah satu teknik influentif yang paling menunjukkan keberhasilannya dalam menyiapkan dan membangun moral anak (Abdullah Nashih Ulwan, 1988 : 2).

Dengan teknik ini, peserta didik akan berusaha menerima pesan yang disampaikan kepadanya. Sebab secara psikologis peserta didik suka mencontoh perilaku sosok atau figur yang menjadi idolanya, termasuk di dalamnya guru. Guru sebagai figur teladan memiliki tugas yang berat, sebab setiap saat guru menampilkan jiwa keutamaan. Dengan ungkapan lain, keteladanan senantiasa menuntut sikap yang kontinu serta konsisten, baik dalam budi pekerti luhur ataupun perbuatan terpuji (Khatib Ahmad Santhut, 1998 : 85). Dengan adanya kesinambungan tersebut, maka 
anak didik akan semakin mantap dalam perilakunya. Sikap konsisten ini dilakukan dengan pijakan teguh pada perihal apa saja yang telah dikatakannya. Sebagai bukti bahwa guru konsisten dan kontinu yaitu ia mau memberi contoh dan juga mempraktekkannya dalam kehidupan real atau nyata keseharian. Selaku orang yang dewasa, guru sebaiknya tidak cukup sekedar memberi contoh, akan tetapi selalu menjadi contoh dalam kehidupan keseharian (Mustaqim dan Abdul Wahib, 2001: 45). Apabila guru hanya memberi contoh, maka ia bagaikan bermain sandiwara; ia hanya berbuat pura-pura sebab guru hanya menunjukkan norma yang hendak dipunyai oleh anak didik, namun perwujudannya tidak kasatmata dalam kehidupannya.

Dalam psikologi, pentingnya keteladanan menjadi metode pendidikan diasaskan atas adanya insting atau gharizah agar selalu beridentifikasi dalam diri masing-masing individu (Abdurrahman an-Nahlawi, 1995: 231).

Tujuan beridentifikasi tersebut yaitu agar ia menjadi identik atau sama dengan tokoh identifikasinya. Oleh karenanya, segala sesuatu yang wujud atau ada serta dilakukan oleh tokoh identifikasi akan selalu diikuti. Sebab guru selalu sebagai sorotan, terlebih bagi anak didik, maka sudah menjadi tanggung jawabnya agar guru mampu mewujudkan dirinya sebagai figur teladan bagi anak didiknya. Perihal ini sesuai dengan istilah Ki Hajar D. yang telah menyatakan guru itu sebagai: 'ing ngarso sung tulodo' yang berarti bahwa seorang guru sebagai penguasa atau orang yang posisinya berada di depan, hendaknya mampu memberikan teladan yaitu dengan menjalankan norma-norma kehidupan dalam kesehariannya.

Seorang guru yang tidak mampu mewujudkan dirinya menjadi panutan atau teladan bagi peserta didiknya, merupakan guru yang gagal dalam melaksanakan tugas utamanya. Seorang guru tidak mudah dapat menjalankan tugasnya dengan sebenarbenarnya, kecuali kalau ia mempunyai kewibawaan dan pengaruh dalam hati muridmuridnya. Kewibawaan menjadikan sesuatu yang urgen untuk diwujudkan oleh setiap guru. Guru berwibawa itu berarti ia mempunyai kesungguhan, mempunyai suatu kekuatan, mempunyai suatu hal yang dapat memberikan pengaruh dan kesan (Cece Wijaya, 1992 : 23). Kewibawaan ini akan menambah kepercayaan anak didik untuk menjadikan gurunya sebagai figur yang patut ditiru. Dengan kata lain, kewibawaan tersebut akan menjadi pengaruh terhadap orang lain, terutama anak didik. Namun, pengaruh dan kewibawaan tersebut hanya ada, apabila guru mempunyai kepribadian 
yang kuat (Mahmud Yunus, 1983 : 72). Kepribadian yang kuat ini berkaitan dengan tugas yang diembannya.

Kepribadian menjadi sifat mendasar yang tercermin serta tergambar dalam sikap seseorang. Sifat mendasar tersebut meliputi unsur fisik maupun psikis. Dengan demikian, semua sikap maupun perbuatan individu merupakan suatu cerminan dari kepribadian seseorang tersebut, tidak terkecuali guru RA berprestasi. Guru menjadi orang tua kedua dari anak yang bertugas membina kepribadian anak didiknya. Dan tidak mungkin guru mampu menjalankan semua tugas tersebut dengan baik, bila guru tersebut tidak mempunyai kepribadian terlebih dahulu (Wawancara dengan subyek pertama sebagai gupres I Ibu Sri Ngadiyati, pada tanggal 18 September 2019). Dalam kehidupan di dunia ini dijumpai banyak manusia dengan berbagai sifat yang dimilikinya. Ada yang sifatnya beda, ada yang mirip, dan bahkan ada pula yang sama. Namun apabila dilihat akan muncul banyak deretan sifat atau karakteristik kepribadian manusia yang ada di sekitar mereka. Sifat-sifat itu juga pada dasarnya telah ada di setiap diri manusia. Tergantung dia mau mengembangkan yang mana. Dari sejumlah sifat yang terdapat pada diri individu, ada sedikit yang menonjol sehingga sifat yang menonjol tersebut mudah diketahui oleh setiap orang. Itulah kepribadian(Wawancara dengan Rina Wahyuni, pada 28 September 2019).

Secara umum, kepribadian guru mencakup 3 (tiga) hal, ialah: pengamalan atau penghayatan nilai-nilai kehidupan atau values, motivasi kerja, serta sifat dan sikap (W.S. Winkel, 2007:110).

a. Penghayatan kepada nilai-nilai kehidupan (values)

Seorang guru berpedoman kepada nilai-nilai tertentu. Nilai- nilai tersebut merupakan pedoman atau pegangan bagi setiap guru dalam menjalankan fungsi dan tugasnya. Hal ini akan nampak dalam pembicaraan dan tingkah lakunya di depan kelas. Jadi, disamping menyampaikan hal-hal yang termaktub dalam kurikulum pengajaran dan buku-buku pelajaran, guru juga harus menyampaikan pesan-pesan kepada siswa tentang nilai-nilai kehidupan.

Pendidikan merupakan suatu usaha untuk mempengaruhi anak didik, sehingga guru hendaknya mampu mengajak murid untuk berpikir dan berijtihad sehingga mereka tidak semata-mata menerima materi yang disajikan atau diajarkan oleh guru (Armai Arief, 2002:74). Kebanyakan anak didik hanya mengambil apa yang tampak dan memahaminya secara mentah. Mereka kurang dan bahkan tidak memperhatikan 
nilai-nilai yang tersembunyi di belakang sesuatu yang abstrak. Sebagai pembimbing, guru harus membawa anak didik supaya mampu berhasil menghayati nilai-nilai dalam kehidupannya. Dan menjadi bukti bahwa guru menghayati nilai- nilai dalam kehidupannya yaitu dengan menampilkan akhlak yang mulia dalam setiap kesempatan.

Keuletannya, misalnya: di sekolah sampai sore-sore kalau sedang mempersiapkan sesuatu kegiatan seperti mau lomba. Begitu juga menyelesaikan masalah/problem solving, sebagai kepala dituntut dapat memutuskan sesuatu untuk menyelesaikan problem seperti perihal yang harus dikerjakan terlebih ketika ada PPL, membagi beragam tugas masing-masing (Wawancara dengan ibu Yuni di RA Masyithoh Kantongan pada 10 September 2019). Perihal kesabarannya: menangani anak juga kreativitas dalam menyediakan variasi kegiatan, fokus dalam melakukan sesuatu seperti memiliki target-target untuk anak dalam mengikuti perlombaan, juga kesabaran menghadapi sikap semua guru, serta apabila ada apa-apa mengutamakan agar selalu bermusyawarah untuk mufakat. Keuletan ibu Sri demi untuk kemajuan sekolah dengan berbagai cara tanpa merasa bosan atau lelah demi kemajuan sekolah, keuletan untuk mengenali potensi anak, dan sebagai pemimpin sekolah yang banyak memberi kelonggaran atau kebijakan kepada para guru (Wawancara dengan ibu Yuni di RA Masyithoh Kantongan pada 10 September 2019).

Seorang guru tidak selalu sukses dalam mendidik muridnya, kecuali kalau ia berakhlak mahmudah atau mulia serta berbudi luhur (Mahmud Yunus : 15). Dengan tampilan akhlak yang mulia tersebut, maka kepribadian guru mampu dinilai, terutama oleh anak didik.

b. Motivasi Kerja

Guru mempunyai motivasi yang luhur dalam melaksanakan tugasnya. Karena tugas guru sangat serius dan berat, sehingga guru tidak mungkin akan melaksanakan berbagai tugasnya dengan terpuji jika ia tidak mempunyai motivasi yang kuat. Motivasi tersebut yaitu apakah seorang guru bekerja hanya untuk memperoleh pendapatan semaksimal atau sebanyak mungkin, ataukah untuk mengorbankan tenaga serta pikirannya bagi tumbuh kembangnya generasi muda. Motivasi tersebut akan menghiasi tingkah laku seorang guru. Seorang guru yang memang bercita-cita mengorbankan keahliannya, ia akan melihat pekerjaannya menjadi sumber kepuasan individu (Winkel : 111). Dengan mempunyai landasan tersebut, maka guru akan rela 
menyumbangkan tenaga dan waktunya dalam melaksanakan tugasnya tersebut. Dan ia akan senantiasa berusaha menjalankan tugasnya dengan seoptimal mungkin.

Dalam melaksanakan tugasnya, seorang guru selalu siap stand by mencukupi kebutuhan jasmani maupun rohani anak dalam pertumbuhannya (Team Didaktik Metodik Kurikulum IKIP Surabaya, 1993 : 12). Untuk memenuhi kebutuhan jasmani, guru mampu menjalankannya dengan menampilkan sikap yang baik dengan harapan anak didik dapat dengan mudah menangkap pesan yang diberikan. Pemenuhan kebutuhan rohani merupakan tugas guru yang lebih berat, karena menyangkut jiwa seseorang. Namun, tugas berat ini tidak akan terasa apabila guru mempunyai motivasi yang luhur.

Motivasi tersebut akan merangsang dan mendorong serta memberikan penguatan untuk menjadi dinamis potensi siswa, mengembangkan swadaya atau aktivitas dan kreativitas atau daya cipta, pada akhirnya akan muncul gairah belajar (Sardiman A.M., 2011 : 141). Dengan dorongan tersebut, maka guru akan selalu bersemangat dalam melaksanakan tugasnya. Hal ini berakibat pada anak didik, anak didik yang melihat gurunya mempunyai motivasi yang tinggi, maka mereka akan merasa lebih terpacu untuk menjalani hari-hari di sekolahnya. Motivasi berprestasi menjadi hal yang penting untuk diamati sebab berdampak pada produktivitas individu yang selanjutnya dapat meningkatkan produktivitas organisasi (Diana Ma'rifah, 2017: 40) Guru mengalami dan memahami bahwa segala tindakan dan usahanya mempunyai sebuah pengaruh di masa depan. Oleh karena itu terkait dengan dorongan berprestasi, guru memiliki kesadaran bahwa keberhasilan mereka di masa depan akan ditentukan dari seberapa keras usaha mereka untuk mewujudkannya, sehingga mereka memiliki dorongan untuk berprestasi dan meraih kesuksesan dalam bekerja. Pernyataan yang disampaikan Rina Wahyuni bahwa:

"Kata kunci yang selalu saya praktikkan yaitu ketelatenan. Setiap murid memiliki sifat perilaku atau karakteristik yang beraneka ragam antara satu dengan lainnya. Masing-masing butuh penanganan, terlebih apabila di kelas tersebut anak yang spesial. Sebetulnya sudah banyak berbagai buku yang menguraikan tentang siapa dan bagaimana seseorang menjadi sosok guru yang baik, namun kadang malas baca. Kadang sudah baca tetapi malas menerapkan, kadang sudah berusaha menerapkan tetapi kurang telaten. Saya meyakini apabila seorang guru bisa telaten mendampingi murid-muridnya, ia akan tahu lebih detail perkembangan mereka, kelebihan atau kekurangan mereka. Pengetahuan detail tentang murid akan menjadi petunjuk bagi guru untuk bisa memberikan 
pendampingan yang tepat kepada murid-muridnya" (Wawancara dengan Rina Wahyuni, pada 28 September 2019).

\section{c. Sifat dan Sikap}

Sifat merupakan ciri yang menyatu pada diri seseorang dan sifat tersebut tercermin dalam sikap yang ditampilkannya. Segala sikap, tutur kata, cara berpakaian, penampilan, cara mengajar pribadi guru sangat mempengaruhi pribadi anak didik. Pribadi guru yang berkarakter pendidik, lebih banyak memberikan pengaruh kepada peserta didiknya melalui tingkah lakunya, apabila dibandingkan dengan pengaruh nasihat dan petunjuk (Muhammad Abdul Qadir Ahmad, 2008 : 61). Pengaruh yang hanya dilakukan dengan nasihat dan petunjuk akan sampai pada anak didik sambil lalu. Namun, dengan pengaruh tingkah laku yang kontinu terus-menerus, maka anak didik akan terpengaruh dengan mudah.

Perilaku guru merupakan satu keutuhan antara peranannya dan sifat-sifat pribadinya sebagai pengajar, pendidik, dan pembimbing (Sukmadinata, 251). Sebagai pendidik, tugas utamanya guru menumbuhkan nilai-nilai keutamaan. Dan agar nilainilai tersebut menjadi bermakna, maka guru telah menguasai nilai-nilai tersebut, yakni dengan menciptakan dirinya menjadi teladan dalam setiap kesempatan. Guru sebagai pengajar berkewajiban menyampaikan ilmu dan pengetahuan kepada peserta didiknya.

Anak-anak yang diamanahkan oleh orang tuanya kepada sekolah dan dipercayakan untuk dididik oleh semua guru yang di sekolah tersebut, mereka adalah peserta didik (Wawancara dengan Rina Wahyuni, pada 28 September 2019). Oleh karenanya guru berusaha untuk mengetahui sekaligus menguasai segala hal tentang keilmuan yang diajarkannya. Sebagai pembimbing, guru bertugas membantu peserta didik guna mengatasi kesulitan yang dihadapi. Agar bisa melakukan perannya dengan terpuji, maka guru telah memahami anak didiknya. Tugas mulia seorang guru yaitu membuat kepribadian anak didik. Agar seorang guru mampu membentuk kepribadian dari anak didiknya, maka guru mendahulukan tentang pemahaman karakteristik (ciri khas) kepribadian dirinya. Hal tersebut menjadi penting, sebab guru menjadi panutan serta teladan untuk peserta anak didiknya, sekaligus akan berimbas pada keberhasilan dalam profesinya (Wawancara dengan Sri Ngadiyati pada 27 September 2019).

Pada waktu kegiatan jam istirahat, guru wajib turun keluar kelas. Semua guru ikut mendampingi anak. Sedangkan guru berpretasi biasa ikut nimbrung bermain 
seperti bermain bola dan lain-lain. Saat bermain bisa sekalian berinteraksi, bertanya ini itu, jadi akan makin dekat dengan anak. Perihal problem solving yang dilakukan biasa pendekatan ke anak, berbicara dari lubuk hati sanubari (hati ke hati). Bila ada yang berselisih biasanya saya diskusi dengan anak yang berselisih, mendengar penjelasan masing-masing sehingga dapat segera terselesaikan. Problem solving ke orang tua wali peserta didik, biasanya ketemu langsung, sambil saya tunjukkan catatan anekdot siswa yang bersangkutan (Wawancara dengan bapak Anton Ariyadi di RA Baitur Rahman pada 14 September 2019). Menurut Muhibbin Syah, karakter kepribadian yang terkait dengan keberhasilan guru, meliputi 2 hal, yaitu: keterbukaan psikologis serta fleksibilitas kognitif (Fleksibilitas kognitif (keluwesan ranah cipta) merupakan kemampuan berpikir yang diikuti dengan tindakan secara simultan dan memadai dalam situasi tertentu. Guru yang fleksibel pada umunya ditandai dengan keterbukaan berpikir dan beradaptasi. Ia juga memiliki resistensi (daya tahan) terhadap ketertutupan ranah cipta yang terlalu dini dalam pengamatan dan pengenalan. Dalam Muhibbin Syah, 2011 : 226). Pribadi guru yang fleksibel, ketika mengamati sesuatu, ia akan selalu berpikir kritis yakni selalu menggunakan akal sehatnya untuk mengambil keputusan. Keputusan tersebut berupa apakah ia akan mempercayai (menerima) sesuatu atau mengikuti (menolak) sesuatu tersebut.

Keterbukaan psikologis pada diri pribadi seorang guru, biasanya dibuktikan dengan kesanggupannya relatif tinggi untuk mengemukakan atau mengenalkan dirinya dengan berbagai faktor ekstern, yakni teman sejawat, siswa, dan lingkungan pendidikan. Komunikasi ini dapat terjalin dengan bersedia menerima kritik atau masukan dengan ikhlas, memiliki simpati dan empati terhadap orang lain. Keterbukaan psikologis menjadi ciri khusus kepribadian yang sangat dibutuhkan bagi guru dalam kaitannya sebagai direktur belajar, disamping sebagai panutan bagi siswanya (Muhibbin Syah, 2011 : 227). Dengan keterbukaannya tersebut, maka guru akan berhasil dalam mengatur kegiatan pembelajaran. Sementara itu, seorang guru akan dapat melengkapi kebutuhan anak didiknya dengan baik.

Kepribadian guru sebagai satu kesatuan antara peranannya dan sifat-sifat pribadinya, sebagai pengajar, pembimbing, serta pendidik (Sukmadinata, 252). Kepribadian guru ini sangat memegaruhi proses semangat belajar anak didik. Oleh karenanya guru mengenal sifat-sifat yang harus dikuasai terlebih dahulu. Beberapa sifat yang selalu dimiliki atau dikuasai guru menurut Zakiah Daradjat, antara lain: 
penyayang, suka bekerjasama secara demokratis, mengahargai kepribadian peserta didik, sabar, mempunyai pengalaman, pengetahuan, serta ketrampilan yang beragam, berkelakuan baik dan perawakan yang menyenangkan, tidak memihak dan adil, toleran, mantap dan stabil, memperhatikan permasalahan anak didik, menghargai anak didik dan mampu memuji perilaku baik, lincah, cukup dalam pengajaran, dan mampu memimpin dengan baik (Zakiah Daradjat, 2005 : 37-38).

Sementara menurut Muhammad Athiyah, seorang guru harus mempunyai berbagai sifat di antaranya yaitu: zuhud, menjaga kebersihan diri, ikhlas dalam pekerjaannya, menjadi bapak sebelum ia sebagai seorang guru, pemaaf, mengenal tabiat murid (Muhammad Athiyah al-Abrasyi, 1974 : 131-133). Mahmud Yunus juga mengemukakan pendapat, sebagaimana dalam Armai Arief bahwa ia menghendaki agar seorang guru muslim hendaknya mempunyai sifat sebagai berikut: menyayangi muridnya, selalu memberi nasihat kepada muridnya dengan bijak, tidak merendahkan pelajaran yang lain, mengajak murid untuk berpikir dan berijtihad sehingga tidak semata-mata menerima materi yang diajarkan guru, perihal materi yang mudah pada masa awal-awal dan materi tersebut banyak terjadi di masyarakat, serta memperlakukan murid dengan adil (Armai Arief, Pengantar Ilmu dan Metodologi Pendidikan Islam, 74).

Sedangkan An-Nahlawi, menguraikan bahwa setiap guru mempunyai sifat sebagai berikut: hendaknya tujuan, pola pikir guru dan tingkah laku bersifat rabbāni, ikhlas, sabar dalam mengajarkan pengetahuan, jujur dalam menjalankan apa yang diserukannya, mempersiapkan diri dengan ilmu pengetahuan dan senantiasa mengkajinya, mampu dan trampil memanfaatkan berbagai metode mengajar dengan bervariasi, mengelola peserta didik, dalam bertindak tegas, serta meletakkan segala persoalan secara proporsional, menguasai mata pelajaran, memahami kehidupan psikis para peserta didik, tanggap dan sigap terhadap berbagai situasi, kondisi serta perkembangan dunia, berlaku adil di antara individu peserta didiknya ( Abdurrahman an-Nahlawi : 170-175).

Menurut Ag. Soejono, sifat kepribadian yang dipunyai oleh guru untuk melaksanakan tugasnya dalam bergaul dengan anak didik yaitu: rasa tanggung jawab; kecintaan, kesabaran, dan kebijaksanaan; berpandangan luas, serta pandai bergaul (Ag. Soejono, 1980 : 47-48). Seorang guru harus menyadari bahwa dirinya telah dipercaya oleh wali peserta didik untuk mendidik putra-putri mereka, sejak mereka 
mendaftarkan putra-putrinya ke sekolah. Oleh sebab tersebut, guru hendaknya menjalankan kewajiban dan tugasnya dengan sangat baik. Apabila guru tidak menjalankan tugasnya dengan terpuji, maka kepercayaan para orang tua akan hilang.

Jika dilihat dari perannya, guru sebagai petugas sosial (social workers), sehingga ia penting memiliki sifat sosial dan budi pekerti, yaitu: cinta dan percaya pada masyarakat sekitarnya, peka terhadap perubahan masyarakat dan lingkungan hidup, mudah bergaul dan beradaptasi dengan kehidupan baru tanpa kehilangan kepribadiannya, senang dan mudah ikut bekerja untuk perbaikan sesame-sama manusia, juga kepada masyarakat sekitarnya maupun ekologinya; akrab, senang, mudah bergaul, dan aktif bekerjasama untuk kepentingan umum dalam berbagai tugas sosial, tidak mempunyai nilai diri yang kurang lengkap, tetapi tidak juga dihinggapi perasaan merasa harga diri superior maupun juga suka menonjolkan diri, mampu dan sanggup memimpin maupun dipimpin, bersikap demokratis dalam pergaulan hidup, suka bergotong-royong atas dasar kekeluargaan, bebas dari rasa sukuisme, daerahisme maupun agamisme (Ag. Soejono, $1980: 51-52$ ).

Pasaribu dan Simandjutak menguraikan beberapa sifat guru yang terpuji antara lain: menganut serta mendarahdagingkan falsafah negara, mengenal dan menggunakan prinsip dasar didaktik (informative) dalam setiap mengajar, mengetahui kondisi dan situasi serta menghormati peserta didik sebagai subyek didik. Guru hendaknya meniadakan diri pribadi dari sifat otoriter, menghargai materi pembelajaran yang akan disampaikan. Hal ini bisa dijalankan dengan menguasai bahan dan mengetahui manfaatnya, dapat menyesuaikan metode mengajar dengan materi pelajaran, memahami perbedaan individu, membentuk pribadi anak, mempunyai mental yang sehat, memiliki persiapan yaitu; merumuskan dan menentukan tujuan dari pengalaman belajar itu sendiri, dan menyusun rencana strategi pengajaran, serta menyusun rencana untuk menilai efektivitas dari rencana strategi pengajaran (I.L. Pasaribu dan B. Simanjuntak, $1980: 73-74)$.

Sifat-sifat tersebut akan mampu ditiru bagi peserta didik melalui penampilannya. Menurut Zakiah Daradjat, penampilan kepribadian tersebut meliputi: perasaan dan emosi tampak optimis, menyenangkan, dan stabil, moral atau tingkah laku, sikap guru dalam menempuh berbagai persolan, sikap guru pada agama, cara guru berjalan, berbicara, berpakaian, serta bergaul (Daradjat, 11-13). 
Guru dalam bahasanya, Muhaimin menyebutkan bahwa seorang guru semestinya mampu menjadi profil guru yang diharapkan, yakni mempunyai kepribadian yang menyangkut aspek personal dan profesional (Muhaimin, Sutìah, dan Nur Ali, 2004 : 97). Kedua aspek ini akan mempengaruhi hasil dari proses pembelajaan yang dilaksanakan. Kemantapan pribadi individu guru yang diimbangi dengan profesionalisme akan memberikan kesempatan yang luas kepada guru agar dapat menjalankan fungsinya dengan baik.

\section{Simpulan}

Penyebab utama profesionalisme guru menjadi rendah adalah: (1) Banyak guru belum memenuhi profesinya secara menyeluruh berkelanjutan, (2) Rendah dan rentannya kepatuhan guru terhadap nilai atau norma serta etika profesi atau akhlak keguruan, (3) Pengesahan terhadap ilmu keguruan dan pendidikan masih belum utuh dan bulat dari beberapa pihak terlibat dalam pengambilan kebijakan. Terbukti masih kurang mapannya kelembagaan yang melahirkan tenaga kependidikan dan keguruan, (4) Masih kurang smoothnya perbedaan paradigma tentang proporsi atau keseimbangan bahan ajar yang dimodalkan kepada calon guru yang profesional, (5) Masih kurang berfungsi PGRI secara optimal sebagai lembaga atau organisasi profesi yang berusaha semaksimal untuk meningkatkan profesionalisme para anggotanya.

Manajemen kecakapan Intrapersonal dapat ditinjau dari dirinya sebagai makhluk individu, di mana setiap individu memiliki softskill yang bisa dikembangkan. Misalnya tekun, rajin, ramah, dan lain-lain. Sedangkan interpersonal merupakan kecakapan seorang guru ditinjau dari dirinya sebagai makhluk sosial, di mana keberadaannya selalu membutuhkan bantuan orang lain, butuh keterhubungan dan saling bekerjasama dengan manusia lainnya. Misalnya berbagi tugas dalam suatu kepanitiaan, aktif di organisasi soasial kemasyarakata dan lain-lain.

Guru harus memiliki perasaan dan emosi yang menyenangkan, stabil, serta optimis. Hal tersebut mampu memikat hati dan menaruh perhatian peserta didik, karena setiap peserta didik merasa disayangi dan diterima oleh gurunya, walau bagaimanapun tingkah laku mereka. Moral atau tingkah laku juga menjadikan penampilan atau sikap kepribadian seseorang, terlebih bagi guru. Bila akhlak atau tingkah laku guru tidak terpuji, maka pada umumnya akhlak peserta didik juga akan rusak karenanya. Semua ini terbentuk karena anak mudah dipengaruhi oleh orang yang dipujanya, atau bisa jadi menyebabkan anak didik cemas, gelisah, terganggu 
Fu`ad Arif Noor

emosinya karena mereka menemukan contoh yang berlawanan atau berbeda dengan contoh yang saat ini diperolehnya dari orang tua serta keluarganya di rumah. 


\section{Daftar Pustaka}

A.M., Sardiman. (2011). Interaksi dan Motivasi Belajar Mengajar. Jakarta: Raja Grafindo Persada.

Abdurrahman, Muhammad bin. (1991). Mukhtasar Minhaj al-Qashidin. Libanon: Maktabah Dar al-Lubnan.

Abrasyi (al-), Muhammad Athiyah. (1974). Dasar-Dasar Pokok Pendidikan Islam, terj. Bustami A. Gani dan Djohar Bahry. Jakarta: Bulan Bintang.

Ahmad, Muhammad Abdul Qadir. (2008). Metodologi Pengajaran Agama Islam. Jakarrta: Rineka Cipta.

Arief, Armai. (2002). Pengantar Ilmu dan Metodologi Pendidikan Islam. Jakarta: Ciputat Pers.

Arifin, Imron. (2001). "Profesionalisme Guru: Analisis Wacana Reformasi Pendidikan dalam Era Globalisasi”. Simposium Nasional Pendidikan di Universitas Muhammadiyah Malang.

Connell, W.F. (1974). The Foundation of Education. New York: Holt Rinehart and Winstons.

Danim, Sudarwan. (2016). Inovasi Pendidikan: Dalam Upaya Peningkatan Profesionalisme Tenaga Kependidikan. Bandung: Pustaka Setia.

Daradjat, Zakiah. (1995). Pendidikan Islam dalam Keluarga dan Sekolah. Jakarta: Ruhama.

Daradjat, Zakiah. (2005). Kepribadian Guru. Jakarta: Bulan Bintang.

Daradjat, Zakiah. (2005). Kepribadian Guru. Jakarta: Bulan Bintang.

Djamarah, Syaiful Bahri. (2005). Guru dan Anak Didik dalam Interaksi Edukatif: Suatu Pendekatan Teoritis Psikologis. Jakarta: Rineka Cipta.

Fatimah, Khoiri. (1998). Al-Akhlaq al-Islamiyah li an-Nasyi`ah. Bairut: Dar al-Khoir.

Haryanto, Samsi. (1994). Pengantar Teori Pengukuran Kepribadian. Surakarta: Sebelas Maret University Press

Imron, Ali. (1995). Pembinaan Guru di Indonesia. Jakarta: Dunia Pustaka Jaya.

Kunandar. (2007). Guru Profesional Implementasi Kurikulum Tingkat Satuan Pendidikan (KTSP) dan Persiapan Menghadapi Sertifikasi Guru. Jakarta: Raja Grafindo Persada.

Ma'rifah, Diana. (2017). "Locus of Control Pada Guru dan Lingkungan Kerja Non Fisik; Pengaruhnya terhadap motivasi Berprestasi”, Jurnal Fokus Bisnis, Vol. 16, No. 02, Bulan Desember 2017, 40. https://journal.stieputrabangsa.ac.id/index.php/ fokbis/article/view/140/112 diakses 22 September 2019. 
Marimba, Ahmad D. (1980). Pengantar Filsafat Pendidikan Islam. Bandung: alMa'arif.

Moleong, Lexy J. (2005). Metodologi Penelitian Kualitatif. Bandung: Remaja Rosdakarya.

Muhaimin., Sutìah., dan Nur Ali. (2004). Paradigma Pendidikan Islam. Bandung: Remaja Rosdakarya.

Mujtahid. (2011). Pengembangan Profesi Guru. Malang: UIN Maliki Press.

Mustaqim. dan Abdul Wahib. (2001). Psikologi Pendidikan. Yogyakarta: Pustaka Pelajar.

Nahlawi (an-), Abdurrahman. (1995). Pendidikan Islam di Rumah, Sekolah, dan Masyarakat. terj. Shihabuddin. Jakarta: Gema Insani Press.

Nahlawi (an-), Abdurrahman. (1995). Pendidikan Islam di Rumah, Sekolah, dan Masyarakat, Terj. Shihabuddin. Jakarta: Gema Insani Press.

Nasution, S. (2003). Metode Penelitian Naturalistik Kualitatif. Bandung: Tarsito.

Pantiwati. (2011). 'Upaya Peningkatan Profesionalisme Guru Melalui Program Sertifikasi Guru Bidang Studi (untuk Guru MI dan MTs)". Makalah Dipresentasikan. Malang: PSSJ PPS Universitas Malang.

Pasaribu, I.L. dan B. Simanjuntak. (1980). Proses Belajar Mengajar. Bandung: Tarsito.

Pidarta. (1999). Pemikiran tentang Supervisi Pendidikan. Jakarta: Bina Aksara.

Poerwadarminta, W.J.S. (2006). Kamus Umum Bahasa Indonesia. Jakarta: Balai Pustaka.

Ramayulis. Ilmu Pendidikan Islam. Jakarta: Kalam Mulia.

Rohmadi, Muhammad. dan Yakub Nasucha. (2015). Dasar-dasar Penelitian: Bahasa, Sastra dan Pengajaran. Surakarta: Pustaka Briliant.

Sagala, Syaiful (2013). Kemampuan Profesional Guru dan Tenaga Kependidikan. Bandung: Alfabeta.

Santhut, Khatib Ahmad. (1998). Menumbuhkan Sikap Sosial; Moral dan Spiritual Anak dalam Keluarga Muslim. terj. Ibnu Burdah. Yogyakarta: Mitra Pusaka.

Semiawan, Conny R. dkk. (1991). Mencari Strategi Pengembangan Pendidikan Nasional Menjelang Abad XXI. Jakarta: Grasindo.

Smith, Jhonathan A. (2013). Dasar-dasar Psikologi Kualitatif: Pedoman Praktis Metode Penelitian terj. M. Khozim. Bandung: Nusa Media.

Sodiah. dan Euis Nurhikmah. (2017). "Etika Kerja Kepala Sekolah dalam Meningkatkan Kinerja Guru" Jurnal Studi Manajemen Pendidikan "Tabdir", 
Vol 1, No. 2 Tahun 2017, 185. Diakses 22 September 2019, http://journal.stainc urup.ac.id/index.php/JSMPI/article/view/294/pdf.

Soejono, Ag. (1978). Aliran Baru dalam Pendidikan. Bandung: Ilmu.

Soejono, Ag. (1980). Pendahuluan Didaktik Metodik Umum. Bandung: Bina Karya.

Sukmadinata, Nana Syaodih. (2007). Landasan Psikologi Proses Pendidikan. Bandung: Remaja Rosdakarya.

Supriadi, Dedi. (2005). Mengangkat Citra dan Martabat Guru. Yogyakarta: Adi Cita Karya Nusa.

Sutadipura, Balnadi. (1994). Kompetensi Guru dan Kesehatan Mental. Bandung: Penerbit Angkasa.

Syah, Muhibbin. (2011). Psikologi Pendidikan. Bandung: Remaja Rosdakarya.

Team Didaktik Metodik Kurikulum IKIP Surabaya. (1993). Pengantar Didaktik Metodik Kurikulum PBM. Jakarta: Grafindo Persada.

Ulwan, Abdullah Nashih. (1988). Pendidikan Anak dalam Islam. terj. Saifullah Kamalie dan Hery Noer Ali. Bandung: asy-Syifa'.

Undang-undang RI No. 14 Tahun 2005 Tentang Guru dan Dosen. Bandung: Citra Umbara. Diakses 23 September 2019, http//luk.staff.ugm.ac.id/atur/UU142005GuruDosen.pdf

Wijaya, Cece. dkk. (1992). Upaya Pembaharuan dalam Pendidikan dan Pengajaran. Bandung: Remaja Rosdakarya.

Winkel, W.S. (2007). Psikologi Pengajaran. Jakarta: Gramedia.

Yunus, Mahmud. (1983). Metodik Khusus Pendidikan Agama. Jakarta: Hidakarya Agung. 